\title{
Breathing Bodies
}

Philippa Lovatt, 'Breathing Bodies: Sounding Subjectivity in the War Film', Music, Sound and the Moving Image, Volume 10, Issue 2, 2016.

War is fundamentally embodied. The reality of war is not just politics by any other means but politics incarnate, politics written on and experienced through the thinking, feeling bodies of men and women. (McSorley 2012: n.p)

War films celebrated for their use of sound such as Apocalypse Now (Francis Ford Coppola, 1979), Saving Private Ryan (Steven Spielberg, 1998), The Thin Red Line (Terrence Malick, 1998), The Hurt Locker (Kathryn Bigelow, 2008) and more recently American Sniper (Clint Eastwood, 2014) have tended to focus on the subjective and phenomenological experience of war from the perspective of soldiers, whose agency and placement within the very centre of the action drives the film's narrative (Hochberg 2013: 45). ${ }^{1}$ By contrast, the two Iranian films I will discuss here, Bahram Beizai's Bashu, The Little Stranger (Bashu, gharibeye koochak, 1990) and Bahman Ghobadi's Turtles Can Fly (Lakposhtha parvaz mikonand, 2004), record the experience of war from the perspectives of those whose lives have been radically and violently disrupted by it, but who have had no active role in shaping its outcome. Focusing on the experiences of children, both films use sound design to articulate a sense of their characters' fragmented subjectivity and powerlessness through techniques such as point-of-audition, close-perspective miking, and non-synchronous sound and image. In both films, characters rarely speak about their trauma. Instead, embodied sounds and vocalisations are heard on the soundtrack at key points in the narrative to align the spectator with their perspective while at the same time emphasising their characters' vulnerability at the centre of the larger, global 'sensate regimes of war' in which they have no voice or control (Butler 2012: 110).

In this way, they also have strong affinities with other 'anti-war' films, which although set in very different historical and geographical contexts, also feature children as their central protagonists such as Diamonds of the Night (Démanty noci, Jan Němec, 1964) and Come and See (Idi I smotri, 


\section{Breathing Bodies}

Elem Klimov, 1985). However, there are important differences between them. While Němec and Klimov's films, both set in World War II, were made decades after the events they depict, Bashu was filmed during the Iran-Iraq War (1980-1988) and Turtles during the US invasion of Iraq, shortly before the beginning of the second Gulf War in 2003. Both of the Iranian films feature non-professional child actors, 'indigenous to the world represented in the films', who had themselves lived through this time thereby adding a further level of immediacy and urgency to the performances and the very notion of embodiment that I discuss in this essay (Lury $2010 \mathrm{~b}$ : 285). Through close, comparative analysis of the sound design in each of these films, I argue that sound plays a crucial restorative role by articulating a sense of characters' agency and subjectivity so often denied to civilian victims of war both in official records and in their cinematic representation. As such I claim that the films offer a radical alternative to dominant conceptualisations of war as depicted in Hollywood cinema, challenging and broadening our understanding of the genre, as well as potentially deepening our understanding of the impact of war on the lives of civilians and refugees.

\section{Breath and the sounding body}

In her book The Place of Breath in Cinema, Davina Quinlivan asserts that 'the notion of breathing stimulates new ways in which to question the nature of seeing, perceiving and sensing things which are not always entirely visible in film' (Quinlivan 2012: 1-2). For Quinlivan, breath destabilises and makes permeable the boundaries between self and other, between inside and outside the body, and between the seen and unseen on screen. The audio-visual representation of the respiring body can therefore hold an ambiguous power and fascination. Breath, of course, is often spoken of as the material manifestation of the life force; phrases such as one's 'dying breath' convey poignantly the precariousness of the line between the animated, feeling body, and the corpse. Indeed, a recurrent trope in the thriller genre (and that also occurs in Bashu) is when a character holds up a mirror to an unconscious person's mouth to see if they are still alive: condensation on 


\section{Breathing Bodies}

the glass transforms the exhaled breath from something that is abstract and ephemeral into a visible, tangible signifier of life. Similarly, in the horror/slasher genre, in moments of heightened tension, (usually female) characters hold their breath to avoid being discovered by the killer: the breath itself becomes an audible marker of the victim's vulnerability just as the killer's rasping exhalations evoke his physical proximity and the imminent threat he embodies (Clover 1997: 208). ${ }^{2}$

The breath, like the voice, denotes agency and a sense of self that exceeds the bodily frame that produces it. As Mladen Dolar has described, making a connection between the two: the voice, like breath, leaves the body 'like a bodily missile which separates itself from the body and spreads around' while at the same time emanating from, and expressing, the innermost part of a person:

The voice, by being so ephemeral, transient, incorporeal, ethereal, presents for that very reason the body at its quintessential, the hidden bodily treasure beyond the bodily envelope, the interior "real body", unique and intimate, and at the same time it seems to present more than the mere body - in many languages there is an etymological link between spirit and breath (breath being the "voiceless voice," the zero point of vocal emission); the voice carried by breath points to the soul irreducible to the body. (Dolar 2006: 71)

Breath, like the voice, can express an intensely private subjectivity at the same time as creating an opportunity for an affective, intersubjective connection with others based on an epistemology of embodied memory and experience: what Quinlivan refers to as a 'breathing encounter' between the 'body of the film' and the body of the spectator (Quinlivan 2012: 21; Marks 2000: 153). In film and television, the sonic similarly transcends the limits of the visual frame and partly because of this it is sometimes described as having a spectral, 'otherworldly' quality (Chion 1999: 21; Donnelly 2014). In the Hollywood War film however, the precariousness of the (male) soldier's body under threat is frequently emphasised by graphic images that expose its materiality: blood, torn flesh and 


\section{Breathing Bodies}

lost limbs that are anything but otherworldly and ephemeral. Indeed, the war film has always derived a great deal of its dramatic power by foregrounding the vulnerability of the human frame, the sight and sounds of the body in pain and the pervasive sense of threat to the body in combat. As Robert Burgoyne observes:

Of the many cinematic forms that can be described as body genres, the war film is clearly a defining example, drawing its most memorable scenes and its most intensive cultural meanings from the way the body, both as agent and patient, as living and dead, is depicted. In no other genre is the liminality of the body represented in quite this way. (Burgoyne 2012: 7)

These graphic images are usually accompanied by highly melodramatic, non-diegetic music that underscores the intensity of emotion, sometimes attempting to simulate the sensory experience of an adrenalin rush as the men go into battle or otherwise put themselves in danger. However, at key dramatic moments the absence of music combines with gaps in dialogue to create space within the acoustic ecology of the film to allow for moments of sensory intimacy between the spectator and the characters on screen. In these scenes, the sound of the protagonists' breath is heard high in the mix giving the impression of close auditory proximity and alignment as if we too are involved in the action, fighting alongside the soldiers (who are almost always the central protagonists). Point of audition attunes the listener/spectator to the subjective position of the character, as the 'missile-like' qualities of the breath create a third auditory space that is produced by on and off screen sounds as the breath of the spectator merges with the sounds of breathing emitted through the speakers into the space of reception. In this way, sound design can, and does, affect processes of identification, leading to ethical implications in terms of how we understand narrative events and value some perspectives over others. ${ }^{3}$

For example, the sound design (by Paul Ottoson) in Kathryn Bigelow's The Hurt Locker (2008) set during the American occupation of Iraq, remains unwaveringly tied to the auditory perspectives of 


\section{Breathing Bodies}

Sergeants James and Sanborn (Jeremy Renner and Anthony Mackie), and Specialist Eldridge (Brian Geraghty): members of an elite army bomb squad and the central protagonists of the film. In these scenes, while the men negotiate the extremely dangerous task of de-activating IEDs (Improvised Explosive Devices) while under constant threat of attack from insurgents, the sound design uses rhythm and timbre to convey their heightened state of mental and sensory awareness while simultaneously creating dramatic tension by drawing the spectator into the world of the narrative. In this way, the sound design explicitly attempts to recreate the rush of adrenalin felt by the soldiers for whom (as the film's tagline states) 'war is a drug'. In one of the film's most memorable scenes, in which Sergeant James risks his life in order to de-activate a bomb, the rasp of his breathing, recorded by the communication microphone on the inside of his bomb suit, is prominent in the mix. As Jean Martin describes:

The loneliness of the bomb disposal expert is highlighted by the subjective sound of his breathing, enclosed in the monstrous bomb suit. His breathing is closely recorded through the in-built communication microphone. One can therefore hear the tiny nuances, when James holds his breath, or breathes irregularly because of his tension. This is supported by a subjective camera perspective, moving and shaking, as if the viewer was in the bomb suit. (Martin 2013: 128)

The kinetic energy produced by the formal aspects of this scene through the visceral use of sound and the rapid editing of the image, engages the spectator on a sensory level. However, the spectator is unequivocally aligned with the perspective of the soldier, while the civilians in this scene, and elsewhere in the film, are positioned as the voiceless 'other'. On the one hand therefore, this use of embodied sound serves to emphasise James' vulnerability but on the other hand, it puts forward a sense of the character as a solitary heroic figure fighting a Manichean conflict of good against evil in which the 'sounding' body is the only one that matters. 
Similarly, in Terrence Malick's The Thin Red Line (1998), 'embodied' sounds blur the boundary between self and other, soldier and spectator, and as the title might suggest, life and death. The film, which is adapted from James Jones' 1962 novel, focusses on a group of American soldiers (the Charlie company) whose orders are to take the strategically important island of Guadalcanal in the Solomon Islands from the Japanese during World War II. In a pivotal scene in the film, the Charlie company are ordered to ascend the hill towards the Japanese soldiers who are positioned at the top. Before the shooting begins, which obliterates the tranquillity of the soundscape through its sheer volume and force, we hear the anxious and expectant breathing of the American soldiers, which merges with the soft breeze, as they wait for their instructions from their commander. Here the sounds of breath convey on a visceral level the acute sense of fear and trepidation that the men are experiencing. By contrast, the absence of these embodied sounds from the Japanese characters creates a sensory distance that serves to disavow their subjectivity.

Although a very different film in style and ideological perspective, Jan Němec's Diamonds of the Night also uses breath and a haptic aesthetic to foreground the subjectivity of its central protagonists and forge an emotional, and potentially physiological, connection between the spectator and the characters. Based on the novel by Jewish Czech writer Arnold Lustig, the film focuses on the experience of two boys, who leap from a train bound for a concentration camp in Nazi-occupied Czechoslovakia. Reminiscent of the sparse phenomenological sound design of Robert Bresson's $A$ Man Escaped (Un condamné à mort s'est échappé, 1956), the film deploys aural and visual flashback as the boys run through the forest and surrounding fields as they attempt to escape. It is not at all clear which memories are real and which are imagined as they are played out sometimes as if on a loop; the non-synchronous juxtaposition of sound and image and non-linear narrative (what Max Nelson calls its 'breathless editing', 2013) serves to convey a deeply traumatised perspective that is at the same time intrinsically embodied. In her discussion of Diamonds of the Night in The Child in Film, however, Lury argues that the acoustics seems strangely dislocated: while the diegetic sounds of the train, gun shots, the guards' shouts 'make sense' within the context of what is being shown, the 


\section{Breathing Bodies}

strained breath and grunts of the two boys heard in close aural proximity as they make their escape feel strangely intimate as if 'the boys are right beside the spectator rather than located within the environment of the scene' (Lury 2010a: 116). Without a musical score, the starkness of these embodied sounds means that they merge with our own, as Lury explains:

Our proximity in relation to the sound the boys' bodies make is sustained throughout the film and brings us necessarily close to and intimate with the boys and their plight. Significantly, the emphasis awarded to the small sounds their bodies make as they encounter the environment around them - breathing, sighs, feet sloshing in the mud and the sound of rain falling on their skin - make these sounds (unusually for film) as important as speech. (ibid.: 116117)

Lury goes on to explain that when the boys finally do speak, the spectator is surprised because we have already become involved in the story through the intimacy of the auditory experience, without the need for expository dialogue. It is this impression of embodied 'closeness', I argue, that enables the spectator to 'bear witness' to the experience of war from the perspective of civilians and refugees in the films that I come on to discuss. In The Image and the Witness, Roger Hallas and Frances Guerin contend that ' $[\mathrm{t}]$ he act of bearing witness ... constitutes a specific form of address to an other. It occurs only in a framework of relationality, in which the testimonial act is itself witnessed by an other' (Hallas and Guerin 2007: 10). For film, this 'framework of relationality' suggests an ethical dimension to spectatorship that I contend is enabled in these films through their use of sound. Expanding on Lury's observations of children's performances in war films, in what follows, I demonstrate how the sound design of Bashu, the Little Stranger and Turtles Can Fly encourages a sense of intersubjectivity and empathy between the characters and the spectator. This article is concerned with how the act of listening (as opposed to merely 'viewing') might challenge our conceptualisation of the war genre. 


\section{Breathing Bodies}

\section{Bashu, the Little Stranger}

Like Diamonds of the Night and Come and See, Bahram Beyzaie's Bashu, the Little Stranger focusses on the traumatic effect of war on civilian children. Set in Iran during the Iran Iraq war, the film tells the story of a young boy named Bashu (Adnan Afravian) who stows away in the back of a truck on its way to the north of the country after witnessing his entire family being killed in the bombing. Originally from Khuzestan in southern Iran, he escapes to the Capian region in the rural north where he meets Na'I (Susan Taslimi), a woman who eventually becomes a surrogate mother to him. Although most of the film takes place away from the site of conflict, the war nonetheless forms the backdrop to the entire film and is a destabilizing undercurrent embodied by the recurring vision of a spectral figure dressed in black (Bashu's dead mother played by Moaazez Banidougt), and through the many visual and aural flashbacks that take us back to the shelling attacks on Bashu's home.

Point of view shots and the use of eye-line matches serve to recreate Bashu's perspective throughout the film. However, point of audition is also used to communicate the boy's subjective experience of his changing environment as he travels from the war zone in the south to what seems, by comparison, a rural idyll in the north. The rich aural texture of the film moves between, and often overlays, the sounds of the rural environment such as birds, animals and the wind with human voices that mimic these sounds. Na'I's vocalisations in particular, move effortlessly between the human and the non-human as she communicates with the animal world, mimicking their grunts and calls, an ability that Bashu also later develops. Unlike the Hollywood war film that often seeks to present a sense of mastery over the landscape through the use of wide lens establishing shots, in this film, the acoustic environment seems to assert an agency of its own that co-exists with the animals and humans that inhabit it.

Importantly however, the sonic also triggers painful memories of the absolute devastation that Bashu fled in the south and acts as a reminder that, even if he were able to return, there is 


\section{Breathing Bodies}

nothing left for him to return to, and he is now effectively living in exile. Like Turtles Can Fly, the film immerses the spectator into the action of the film refusing to offer 'a distanced reflection on the events' (Rutherford 2013: 96). Through the non-linear narrative, and often discordant layering of sound and image the temporality of the narrative space is unstable. Sensory triggers such as the sight and sounds of flames in a clay oven cause Bashu's perspective to move rapidly between past and present events highlighting his traumatised state and his somatic, internalised memories of the explosions. As Negar Mottahedeh has described, these events drive the narrative forward as the 'film's production processes mimic Bashu's own body' (Mottahedeh 2008: 25).

While the film's opening credits roll, we see an animated sequence of fighter jets moving steadily from left to right across a black screen set against the acousmatic voices of a group of people (whom we never get to see) singing a rousing Iranian folk song (Chion 1994). This cuts abruptly to chaotic scenes of explosions and bombing: flames and clouds of dust and black smoke fill the screen. A man falls through the floor of his house without warning, a woman dressed in black beats herself while trying to extinguish the flames on her clothes, a young girl runs through the chaos while trying to dodge the explosions. It later becomes clear that we are witnessing the last living moments of Bashu's family and that he is the only one to have survived the attack on their town. On the soundtrack the searing noise of shells hitting the town and the deep bass boom of the explosions is juxtaposed against the high pitched shattering of glass and the deafening noise of buildings collapsing to the ground. The combination of sound and image here expresses the horror and devastation of the war in the south while producing a sensory assault on the spectator (Mottahedeh 2008: 23).

We then see a truck drive out of the town, narrowly missing the explosions that go off all around it. The driver stops and gets out for a moment as he checks the tyres and the image cuts to a shot of Bashu running through a corn field before taking refuge under the tarpaulin in the back. Moments later we witness the truck driving through thick black smoke (heading straight towards the camera). The sound of fighter jets cuts through the air above and merges on the 


\section{Breathing Bodies}

soundtrack with the nondiegetic voices of another group of people singing rhythmically and clapping their hands to the beat. The truck is shown in long shot making its way through the arid landscape, up into the mountains of southern Iran. The driver stops to get some food and then continues on his journey. On the non-diegetic soundtrack the rousing folk song is heard again (in close auditory perspective), this time however, beneath the song low sobbing can be heard: a juxtaposition and layering of sounds that suggests that even when survivors leave, the traumatic memories of the war stays with them. This prologue depicts the bombings from the child's perspective through fragmentary images and nonsynchronous sound, and sets up a mode of formal and temporal instability that continues through the film and is given expression through the embodied sense memories of the boy. As Anne Rutherford notes, 'The trauma exists here in its residue in the child, triggered by the sounds of explosions, the sight of flames and gestural traces that bring forward flashes of his lost family' (Rutherford 2013: 96).

The following morning, Bashu wakes up in the back of the truck when the driver stops to get some breakfast, not far from Na'I's home in the north. The first sound that he hears as he wakes is the soft, lowing of a cow. In contrast to the arid, rocky landscape of the south, here the rural environment is lush and green and the acoustic space, quiet and still (although soon after becoming filled with birdsong and animal noises as the day begins). The peace is disrupted when a controlled detonation goes off as part of a local construction project. Frightened and disorientated, and believing it to be another bomb attack, Bashu jumps out from the truck and begins running through the woods. Against the sounds of him pushing his way through the trees and bushes his breath is clearly audible and continues when the image cuts to a long shot filmed from above of Bashu running across the paddy fields. While the cinematography in this short sequence emphasises the boy's small frame and his vulnerability (being alone in a strange place), the prominence of his quick, shallow breath on the soundtrack at this moment recalls the boys fleeing from the guards in Diamonds of the Night. Like the scene in Němec's film, the closeness of these embodied sounds to the microphone, even though heard only briefly, works in a similar way to align the 


\section{Breathing Bodies}

spectator with Bashu's perspective. Blurring the boundary between diegetic sound and the 'extradiegetic' third space of reception (where the distinction between the character's breath and our own becomes unclear), the sound of his breathing leads to an affective and kinaesthetic engagement that further enables a sense of intersubjectivity and bodily mimesis. In the absence of a musical score, the sound design is stripped down to the basic phenomenological elements of what Michel Chion terms 'materialising sound indices': the soft grass as Bashu's legs brush past it, the wet squelch of mud underfoot, the coarse bark of a dog followed by its soft, moist panting, which overlays the sounds of Bashu's sobs when he stops running (Chion 1994: 114). This is a rare moment in the film which for the most part withholds the very intimate embodied sounds prominent in this scene. The spectator/listener is only given access to Bashu's interiority for a brief time before the aural perspective moves outwards once again to convey the broader auditory space through which he moves. This technique reinforces an awareness of the boy's powerlessness against the larger geo-political events that form the backdrop to his journey.

Recalling the Greek concept of the pneuma (meaning both breath and spirit), here, as in Diamonds of the Night, the sound of the respiring body is a stark reminder of how close the boy has come to death, and how its presence will, quite literally, continue to haunt him in his new adopted environment. As Kamran Rastegar describes, 'Traumatic memory is woven through the fabric of the quotidian, as Bashu frequently experiences hallucinations of his dead parents, and flashbacks to the experience of war' (Rastegar 2015: 162). After Bashu is discovered by two small children, their mother Na'I manages to lure him into her shed to keep him safe during a thunderstorm. Bashu sobs, watched over by three silent figures standing nearby: his mother, father (Nematt Yamini) and sister (Khadijeh Nejat) who were all killed in the war. The figure of the mother dressed in black noiselessly walks past while on the soundtrack the distant rumbling of a storm can be heard. He starts to sob again: 


\title{
Breathing Bodies
}

“Mummy, Mummy...I don't know where I am. Is it still Iran or another land? ...I had parents, my mother was just your size. Oh God, what happened? All of a sudden the floor moved - I heard a splitting noise."

The image cuts to a flashback of his sister running through the smoke. Bashu continues:

\begin{abstract}
"My sister was lost in the smoke. Mother caught fire and burned. Father sank in the earth. I ran to school, our teacher was killed. Oh God, why didn't you take Bashu? Now they're looking for me in the next world. I'm left alone."
\end{abstract}

He puts his head into his hands and sobs. Overhead the crows caw and Na'I calls back to them mimicking their sound. Although Na'I doesn't understand Bashu's words because he speaks in Khuzi Arabic, a dialect from southern Iran instead of her Gilaki Persian, she seems to understand the suffering within them (unlike her neighbours who are suspicious of his dark skin and worry about him bringing bad luck). Rastegar explains that when he arrives at Na'I's home, 'Bashu is fundamentally alienated, not only for his ethnolinguistic difference, but also by the fact that the villagers have no way to comprehend (and he has no language to narrate) his experience of trauma' $(2015,162)$. At one point in the film, the spectator is placed within the visual and aural perspective of some of the other villagers who are openly racist towards Bashu. The ambiguity of aural perspective, in particular in this scene (which takes place immediately after Bashu attempts to describe to Na'I what happened to his family), destabilises the spectator's sensory alignment with Bashu, adding to the sense of uncertainty and unease that is palpable at different points in the film. Yet Na'I's ability to mimetically communicate with the animal world mirrors her instinctive understanding of Bashu's grief without the need for linguistic or semantic knowledge. One of the most striking aspects of Bashu's soundtrack is the fluidity with which human voices, animals sounds and environmental sounds merge into, and echo, each other. At one 


\section{Breathing Bodies}

point, for example, the sound of a horse neighing seems to merge into the sound of a man's laughter as he (along with the other neighbours) mock Bashu over the colour of his skin. The ease with which $\mathrm{Na}$ 'I in particular, relates to the non-human world forms a counterpoint to the total physical and psychological dislocation experienced by the traumatised child. Both of these aspects of the protagonists' relationship with their environment is registered on and through the soundtrack. For the first part of the film Bashu appears shell-shocked: struck dumb by the shock and disbelief of what happened to his family and his home, and evidently afraid that the violence could happen again. When Na'I eventually wins his trust however (and after she also softens towards him), he begins to feel comfortable in his new environment. He copies her mimicry of the animal life around them, making the local boys laugh by squawking like a crow and flapping his arms.

When the family walk home through the paddy fields after visiting the local shop, Na'I and her children loudly bang pots and call out, perhaps to ward off the wild boar that appears later. This event seems to be a pivotal moment in the film. When they return home Bashu reenacts this almost ritualistic act of noise-making: sitting on a bag in the yard, he beats his chest violently and percussively, and through clenched teeth uses his breath to make a rhythmic shuckuh, shuckuh noise. As he calls out, his voice vibrates with each beat further underscoring the vulnerability of his small frame. In this way, Bashu uses his breath and his body as an instrument to communicate suffering that is 'unspeakable' and for which there are no words in either Gilaki Persian or in Khuzi Arabic. As Rutherford describes,

The sound and rhythm give the moment an overwhelming affect. Bashu narrativises this through the catharsis of the body but the film allows a space for intensities that cannot be expressed in the same way through narrative...The moment unleashes an affective excess that lodges this moment 'under the skin,' in the embodied memory of spectators, in ways 


\section{Breathing Bodies}

that resist easy assimilation to the diegesis. It breaks through into the present of spectator experience (Rutherford 2013: 96).

Despite the initial difficulties over language (it later turns out that Bashu can read Persian and Na'I also begins to teach him some Gilaki), voices and vocalisations are nonetheless central to the film in which the act of producing sound is shown to be both life affirming and at the same time, a method of protecting oneself from violence or harm (as with the wild boar mentioned above). Musical performances occur throughout the film and can be considered as further examples of embodied 'noise-making' that is connected to physiological and psychical healing. At one point in the film, Bashu's drumming seems to bring Na'I back to health after a fever, and at another, he plays the flute to encourage the plants in the field to grow.

Within the context of the war film, I argue that these vocalisations and acts of noisemaking perform a vital function in that they reinforce characters' agency and sense of self. Instead of being dehumanised 'collateral damage' in the parlance of modern war discourse, giving voice to civilian and refugee victims of war in these films serves an important political purpose. Suzanne G. Cusick describes the significance of what she terms 'vocalised sound-making' in relation to these questions of power, agency and disempowerment:

Through the interaction of our vocalised sound-making with the sounds we hear other entities make, we are interpolated in a symbolic order, into language and into social relations with the other hearing entities who make sound. The ability to control our interventions in our acoustic environment, as a way of creating and controlling the relationship of our selves to all manner of others, is fundamental to subjectivity as it is commonly construed.' (Cusick 2013: 278) 


\section{Breathing Bodies}

However, recent research in the field of Refugee Studies has suggested that the pressure to produce linear accounts of the 'nation-state' and the historical past has led to the marginalisation of the migrant figure by historians, but also in writing about war. As Philip Marfleet argues in his article, 'Refugees and History: Why We Must Address the Past', the refugee crises currently seen on a global scale are part of the political fallout from colonial legacies and external interventions just as much as a result of local conflicts. As such, refugees are inextricably bound to the power struggles of global history from which they themselves have nothing to gain and everything to lose (Marfleet 2007). The powerlessness of this position is made abundantly clear in the absence of their voices across many forms of mediatised conflict including, but not limited to, Hollywood cinema.

\section{Turtles Can Fly}

Like Bashu, the Little Stranger, Turtles Can Fly, Bahman Ghobadi's third feature film, foregrounds the 'unspeakable' nature of the experience of war from the perspective of a child. The soundscapes of Ghobadi's war films (including A Time for Drunken Horses (Zamani barayé masti asbha, 2000), Marooned in Iraq (Gomgashtei dar Aragh, 2002) and Half Moon (Niwemang, 2006)) by sound designer Bahman Ardalan, are all in some ways 'occupied' acoustic spaces dominated by the sound of Iraqi fighter jets that punctuate and fragment the acoustic space that might in other times have been largely characterised by pastoral sounds (Kara 2009). ${ }^{4}$ While both Bashu and Turtles were filmed on $35 \mathrm{~mm}$, the multilayered Dolby soundtrack used in this film marks a notable contrast with the mono soundtrack of Bashu, recorded and mixed fifteen years previously. The advancement in technology has enabled a much more nuanced and multi-layered rendering of both embodied sounds and the wider acoustic ecology: alongside the sounds of occupation, other sounds emerge in Ghobadi's films such as music and the spoken word that orchestrate a complex heterogeneous space that foregrounds the subjectivity of the films' characters. By amplifying these voices, Ghobadi's films draw on the acoustemology of embodied memory to present an alternative to the dominant accounts of this troubled period in Kurdistan's recent past (Feld 2003). ${ }^{5}$ The defining event of the historical period in which Ghobadi's 


\section{Breathing Bodies}

war films are set stems back to the Iraqi attack on the Kurdish city of Halabja, which took place on March 16th and 17th 1988, after eight years of the Iran-Iraq War. Iraq dropped chemical weapons including mustard gas, tabun, sarin and VX gas on the city, which was then held by Iranian troops and Iraqi Kurdish guerrillas allied with Tehran. The attack killed an estimated five thousand people, leaving many thousands more with long-term health problems. After it was over, the Iraqi army entered Halabja and dynamited the town.

Turtles Can Fly portrays life in a Kurdish community that resides alongside a refugee camp in Northern Iraq on the border with Turkey, just before the US led invasion of Iraq and the fall of Saddam Hussein in the spring of 2003. Through its portrayal of a young girl's experience of rape, and the emotional and physical effects of the war on her and her brother, the film highlights the inadequacy of language in expressing trauma and the silences that emanate from these suppressed histories. The first few moments of the film, before the title sequence begins, show the girl, whose name is Agrin (Avaz Latif), standing on the edge of a cliff. She looks behind her for a moment, and the film cuts to a shot of a person's shadow reflected onto a pool of water as they pass by. It then cuts back to the moment Agrin jumps to her death. As the narrative unfolds, the action goes back in time a couple of days to show us when Agrin and her brother Hengov (Hiresh Feysal Rahman) arrived in the camp. We learn that they are from Halabja, that their parents were killed during the violence and that they planned to go to the border with the rest of the refugees. It emerges that the blind child, Rega (Abdol Rahman Karim), whom Agrin and Hengov have with them, is not their brother, as the other children assume, but Agrin's son. We learn through a flashback sequence that Agrin was raped by soldiers during the Iraqi attack on Halabja, and during this attack she became pregnant with the child.

As Human Rights Lawyer Rhonda Copelon notes, pregnancy as a result of rape 'continues the initial torture in a most intimate and invasive form' (Copelon 1994 cited in Carpenter 2000: 435). Trauma theorist Dori Laub develops this concept of continuation further as she high- 


\section{Breathing Bodies}

lights the durative temporality of trauma in which the victim is 'trapped' in a repetitive pattern of remembering, as she contends:

Trauma survivors live not with memories of the past, but with an event that could not and did not proceed through to its completion, has no ending, attained no closure, and therefore, as far as its survivors are concerned, continues into the present and is current in every respect. The survivor...is not truly in touch with either the core of his (sic) traumatic reality or with the fatedness of its reenactments, and thereby remains entrapped in both. (Laub 1992: 69)

Similarly, Agrin's refusal to acknowledge the child as her son demonstrates that his very existence perpetuates the psychological violence of the rape, both in her conscious mind and in her embodied memory. This creates a fractured sense of temporality as the traumatic past continues to haunt the present through the figure of the child, who is himself 'evidence' of the attack on both Agrin and on Halabja while her constant desire to 'move on' - to leave the camp and the child behind - signifies her need to separate herself from the physical reminders of the attack. ${ }^{6}$

The foregrounding of embodied experience and the way in which this might allow for an empathetic, and potentially also ethical, engagement with film, has particular significance in the rape narrative. In Watching Rape: Film and Television in Postfeminist Culture, Sarah Projansky argues that 'at least since the 1940s, war films have often used representations of women's rapes to tell stories about men' (Projansky 2001: 120). This tendency of the war film to negate the centrality of the female rape victim in these narratives, in films such as Platoon(Oliver Stone, 1986), Casualties of War (Brian de Palma, 1989), and Redacted (Brian de Palma, 2008), is paralleled by the way discussions of rape as an act of war have historically also been marginalised in dominant historiographies. As Copelon notes, 'Most of the time rape has been invisible, or has come to light as part of the competing diplomacies of war, illustrating the viciousness of the conqueror or the in- 


\section{Breathing Bodies}

nocence of the conquered...Military histories rarely refer to rape, and military tribunals rarely either charge or sanction it' (Copelon 1994: 243). According to Shahrzad Mojab, this has also been the case with the Iran-Iraq conflict; as she notes in her essay, 'Vengeance and Violence: Kurdish Women Recount the War', while rarely discussed in either official or unofficial circles, during the Anfal campaign thousands of Kurdish women were abducted and raped by the Iraqi army. According to Mojab, many of those who returned after the fall of Saddam Hussein were subsequently killed by family members because of the shame they felt the women had brought to the family (2000). ${ }^{7}$

Crucially, while cultural discourses of damaged 'honour' seem to absent or negate the woman's body and her own feelings about the rape, just as Agrin's perspective is denied by the patriarchal structures that shape and constrain her world, no matter how often she tries to explain, the film's phenomenological use of sound and in particular, the foregrounding of her breath on the soundtrack, and the use of flashback, heightens our sense of Agrin's embodiment, as well as her subjectivity. In doing so, it repositions the body of the rape victim at the very centre of the war narrative. In the rape scene itself, as Agrin becomes partially submerged in water and is surrounded by disorientating noises, the use of point-of-audition allows the spectator to share her perspective rather than presenting her as 'other' through objective framing, both visually and aurally. By representing rape as an act of war therefore, and importantly of a character who is central rather than peripheral to the narrative, Turtles Can Fly goes some way to making visible and audible the stories of women and girls whose voices are so often absent in historical accounts of conflict and in their cinematic representations.

It soon becomes apparent that Agrin's desire to break away from the maternal role that has been forced upon her is stronger than her desire to live. Later in the film she pleads with her brother to let her leave the child behind for someone to find and look after. 'What will we tell people when he grows up? Shall we say we found him in the streets? What will we tell him when he grows up?' she demands of Hengov. As she asks repeatedly 'what will we say.?' her inability to 


\section{Breathing Bodies}

put into words the horror of her experience becomes tangible. That trauma makes speech inadequate is also borne out by Holocaust survivor Charlotte Delbo, who argues that some experiences cannot be adequately represented through language. Memories of violence, she insists, are 'not known in words, but in the body' (Delbo cited in Culbertson 1995: 170). As this scene progresses, Agrin tells her brother to put the child in between them so he might get some sleep, but he replies that she will not be able to sleep unless she learns to like the child. She answers, 'How many times do I have to tell you? He's not my child.' Hengov begs her not to speak like that and moves over the bed to be closer to the child and brushes his face against his open hand. This gesture, while showing compassion towards the child, denies Agrin that same care. When she tries to communicate her needs to her brother, here, and at other points in the film, Hengov effectively silences her by refusing to acknowledge that the child is not only a reminder of the attack, but his presence is also the continuation of the violence that she experienced. When Agrin winces with toothache, Hengov picks up a bottle of kerosene from the corner of the tent and gives it to her as a painkiller. She takes a sip and holds the liquid in her mouth. As Hengov puts the child between them and tries to comfort him, Agrin moves away and spits out the kerosene. The physical pain she experiences through her toothache is the material manifestation of the psychological pain of trauma. With her mouth full of kerosene (a bitter tasting, poisonous liquid) in order for the numbing effect to work, she has to keep her mouth closed, meaning that she cannot speak even if she wanted to. Unlike Bashu, who seems eventually to be able to occupy a patriarchal role within his adopted family, Agrin seems to be trapped by patriarchal structures within her family, the camp and (as suggested through the many GNN broadcasts shown on television sets throughout the camp) the wider world that pays no attention to her needs.

As Hengov and the boy go back to sleep, Agrin walks out into the darkness and goes to the lake she had been to earlier that day with Satellite (Soran Ebrahim) (a local boy who installs satellite dishes for the elders and organises groups of children to disarm and sell on landmines to arms dealers). Wading into the middle of the water, she pours the remainder of the kerosene over her 


\section{Breathing Bodies}

head and lights her shawl with a match in a startling image reminiscent of the scene in Bashu where we see his mother and sister killed in a shelling attack. As she stands in the water with the flames all around her, she hears the child's voice calling out to her. She sees him on the hillside and follows him back to the tent where she finds him sleeping (he has a rope tied around his ankle, and it is unclear whether Agrin had really seen him by the lake or if she had imagined him being there). Soaking wet and shivering with cold, she tries to cuddle into him, but the child wriggles out of her arms.

Like the clay cooking pot in Bashu, which triggers a flashback to the death of the boy's family, here the image of the flames against the water acts as a sense memory of the rape, which is similarly represented through flashback. As this sequence begins, the camera shows Agrin's feet as she steps slowly forward towards the edge of the cliff, the only sound being the wind blowing around the hillside. On the soundtrack, this bleeds into the frenetic diegetic sound of the flashback sequence in which we hear a cacophony of whooping, artillery fire, and screaming almost drowned out by the noise of the army truck engines relentlessly grinding forward. It is night in the flashback; the truck's headlights flood strips of light onto the chaotic scene as torrential rain pours down creating pools of water in the dirt. Flames flicker all around the frame from the burnt out houses and vehicles reflected in the dark pools of muddy water. The image then cuts back to a shot of Agrin standing a few feet away from the edge of the cliff; again the sound of the wind whirls around her. The contrasting stillness created here is interrupted again by the diegetic sound of the flashback, as we hear Agrin scream followed by a male voice shouting at her. A soldier chases her and slaps her before throwing her to the ground. She gets away but he catches up with her and drags her down into a large puddle - she tries to crawl away but several men drag her back. She claws the waterlogged mud in a vain attempt to escape, but she is surrounded. The men hold her down and rape her. At the moment of the rape, the film cuts to a shot of her arms helplessly flailing. The torrential rain drowns out the diegetic sounds, but we hear her try to catch a breath in aural close-up before being submerged again under the water. 


\section{Breathing Bodies}

As Maureen Turim has discussed, the flashback in film juxtaposes different temporalities and foregrounds formally the relationship between history and memory. She explains, 'If flashbacks give us images of memory, the personal archives of the past, they also give us images of history, the shared and recorded past' (Turim 1989: 2). Flashbacks in film, she argues, frequently merge the different ways of remembering, 'giving large-scale social and political history the subjective mode of a single, fictional individual's remembered experience.' (ibid.: 2) While the circumstances around the rape relate to a much broader historical event (the rape itself is an act of war), Ghobadi foregrounds how this historical event violently affected the lives of ordinary civilians by focussing on Agrin's highly subjective and embodied experience through the use of sound and image. Roberta Culbertson argues that in the recollection of a traumatic event, sounds and images take on a heightened, almost surreal quality perceived not through the conscious mind (which has become 'anesthetized' by the body), but through the senses. Memories of these events, she argues, are characterized by fleeting images but also by 'the percussion of blows, sounds, and movements of the body - disconnected, cacophonous, the cells suffused with the active power of adrenalin, or coated with anesthetizing numbness of noradrenalin' (Culbertson 1995: 178). In the harrowing flashback sequence in Ghobadi's film, the image track is slowed down at the moment of the rape to give a sense of a subjective, and surreal, temporality. Simultaneously, the ambient noise around Agrin and the soldiers at the time of the attack is muted so that the auditory focus is on the sound of Agrin's breath, her sounding body, which, slightly amplified, also emphasises her subjectivity and her agency, even at the very moment that it is most under threat. This use of aural close-up recreates formally what Culbertson refers to as the 'compression of the self in the experience of physical distress', an instinctive reaction that she suggests, functions as part of the 'reductionism of survival' (ibid.: 178).

\section{$\underline{\text { Gonclusion }}$}

In Frames of War: When is Life Grievable? Judith Butler contends that in media representations of war, the invisibility and inaudibility of some lives and the foregrounding of others, evinces the 


\section{Breathing Bodies}

hierarchical imbalance between how different lives are valued and how the senses play a fundamental role in the perception of these differences. As she writes:

The tacit interpretative scheme that divides worthy from unworthy lives works fundamentally through the senses, differentiating the cries we can hear from those we cannot, the sights we can see from those we cannot, and likewise at the level of touch and even smell. War sustains its practices through acting on the senses, crafting them to apprehend the world selectively, deadening affect in response to certain images and sounds, and enlivening affective responses to others. (Butler 2009: 51-52)

She goes on to claim that dominant ways of conceptualising war in the media should be challenged in order to take into account, and act on, the importance of affect in this process - offering new ways of understanding war in relation to, what she terms, 'sensate democracy': a mode of critical (and political) engagement that foregrounds the senses (ibid.: 52). This essay has begun to explore how this concept might be applied to film.

The change brought about by the availability of audio technologies, and the shift from mono to Dolby Digital 2.0, between the production of Bashu, the Little Stranger in the late 1980s and that of Turtles Can Fly, made over a decade later in the early 2000s, means that in many ways, the sound design of these two films is radically different. However, in this essay, I have demonstrated how both films pay close attention to the breathing, sounding bodies of civilian children whose voices are rarely heard in discourses of war. In this way, I have suggested that these films refuse the 'deadening' of affect, and the privileging of some lives over others, that Butler describes above. By foregrounding the voices of civilian victims of war and repositioning them centrally within the war narrative, these films present a crucial alternative to the dominant cinematic depictions of conflict in the Middle East that are deeply entrenched in the colonial imaginary. In doing so, this essay has expanded on Lury's discussion of the child in the war film to 


\section{Breathing Bodies}

consider their position alongside the wider formal politics of the war genre. It has also extended Burgoyne's conception of the 'body at risk' in the genre to consider how attention to the politics of sound design and the ethics of sound and listening in these films, might enable us to reevaluate the 'precariousness' of civilian lives and to question and oppose the dominant conception of which lives 'will become worthy of being mourned' through an affective, sensorial engagement with the films and the embodied experiences of their protagonists (ibid.: 53).

\section{$\underline{\text { References }}$}

Burgoyne, Robert (2012) 'Embodiment in the war film: Paradise Now and The Hurt Locker. Fournal of War and Culture Studies 5:1: 7-19

Butler, Judith (2009) Frames of War: When is Life Grievable?, London and Brooklyn, NY: Verso Butler, Judith (2012) Interviewed in Jon Bailes and Cihan Aksan (eds.) Weapon of the Strong: Conversations on US State Terrorism. New York: Pluto Books

Carpenter, R. Charli (2010) Forgetting the Children Born of War: Setting the Human Rights Agenda in Bosnia and Beyond. New York: Columbia University Press

Chion, Michel (1994) Audio-Vision: Sound on Screen, translated by Claudia Gorbman. New York: Columbia University Press

Chion, Michel (1999) The Voice in Cinema, translated by Claudia Gorbman. New York: Columbia University Press

Clover, Carol (1987) 'Her Body, Himself: Gender in the Slasher Film', Representations, No. 20 (Autumn): 187-228

Copelon, Rhonda (1994) 'Surfacing Gender: Re-Engraving Crimes Against Women in Humanitarian Law', Hastings Women's Law Journal, 5 (2): 243-266

Culbertson, Roberta (1995) 'Embodied Memory, Transcendence, and Telling: Recounting Trauma, Re-establishing the Self', New Literary History, 26.1 (Winter): 169-195 


\section{Breathing Bodies}

Cusick, Suzanne G. (2013) 'Towards an acoustemology of detention in the 'global war on terror', in Georgina Born (ed.), Music, Sound and Space: Transformations of Public and Private Experience. Cambridge: Cambridge University Press, pp. 275-291

Delbo, Charlotte cited in Roberta Culbertson (1995) 'Embodied Memory, Transcendence, and

Telling: Recounting Trauma, Re-establishing the Self', New Literary History, 26.1: 169-195

Dolar, Mladen (2006) The Voice and Nothing More. Cambridge, MA: MIT Press

Donnelly, Kevin J. (2014) Occult Aesthetics: Synchronization in Sound Film, New York and Oxford: Oxford University Press

Ennaji, Moha and Fatima Sadiqi (eds.) (2011) Gender and Violence in the Middle East. Abingdon: Routledge

Feld, Steven, 'A Rainforest Acoustemology' in Michael Bull and Les Back (eds.), The Auditory Culture Reader (Oxford: Berg, 2003), pp. 223-239

Hallas, Roger, and Frances Guerin (eds.) (2007) The Image and the Witness: Trauma, Memory and Visual Culture. London and New York: Wallflower Press

Heineman, Elizabeth D. (ed.) (2011) Sexual Violence in Conflict Zones: From the Ancient World to the Era of Human Rights. Philadelphia: University of Pennsylvania Press

Hochberg, Gil (2013), 'Soldiers as filmmakers: on the prospect of "shooting war" and the question of ethical spectatorship', Screen, 54 (1): 44-61

Kara, Selmin (2009) 'Reassembling the Nation: Iraq in Fragments and the Acoustics of Occupation', Studies in Documentary Film, 3 (3): 259-274

Koebel, Caroline (2009) 'Torture, maternity, and truth in Jasmila Zbanic's Grbavica: Land of My Dreams, Fump Cut, No. 51 (http://www.ejumpcut.org/archive/jc51.2009/Grvbavica/text.html) (accessed 30 August 2016)

Laub, Dori (1992) Testimony: Crises of Witnessing in Literature, Psychoanalysis and History. London: Routledge

Lovatt, Philippa (2015) 'Carceral Soundscapes: Sonic violence and embodied experience in films 


\section{Breathing Bodies}

about imprisonment', SoundEffects, 5(1): 25-39

Lury, Karen (2010a) The Child in Film. London: I.B. Tauris

Lury, Karen (2010b) 'Children in an open world: Mobility as ontology in New Iranian and Turkish Cinema', Feminist Theory, 11(3): 283-294

Marfleet, Philip (2007) 'Refugees and History: Why We Must Address the Past', Refugee Survey Quarterly, 26(3): 146-7

Marks, Laura U. (2000) The Skin of the Film: Intercultural Cinema, Embodiment, and the Senses. Durham and London: Duke University Press

Martin, Jean (2013) 'Landscape, soundscape and taskscape in the films The Hurt Locker (2008), Katalin Varga (2009)', The New Soundtrack, 3(2): 123-136.

McSorley, Kevin (ed.) (2012) War and the Body: Militarisation, Practice and Experience. London: Routledge Mojab, Shahrzad (2000) 'Vengeance and Violence: Kurdish Women Recount the War', Canadian Women Studies, 19(4): 89-94

Mojab, Shahrzad (2004) 'No Safe Haven: Violence against Women in Iraqi Kurdistan' in Wenona Giles and Jennifer Hyndman (eds.) Sites of Violence: Gender and Conflict Zones. Berkeley and Los Angeles: University of California Press, pp. 108-132

Mottahedeh, Negar (2008) Displaced Allegories: Post-Revolutionary Iranian Cinema. Durham, N.C.: Duke University Press

Naficy, Hamid (2012) A Social History of Iranian Cinema, Volume 4: The Globalizaing Era, 1984-2010. Durham and London: Duke University Press

Nelson, Max (2013) 'Off the Blacklist: The Films of Jan Němec', Film Comment, 6 November Projansky, Sarah (2001) Watching Rape: Film and Television in Postfeminist Culture. New York and London: New York University Press

Quinlivan, Davina (2011) The Place of Breath in Cinema. Edinburgh: Edinburgh University Press Rastegar, Kamran (2015) Surviving Images: Cinema, War and the Middle East. New York and Oxford: Oxford University Press 


\section{Breathing Bodies}

Rutherford, Anne (2013) 'Film, Trauma and the Enunciated Present' in Meera Atkinson and Michael Richardson (eds;) Traumatic Affect. Newcastle Upon Tyne: Cambridge Scholars Publishing, pp. 80-102

Thom, Randy (n.d.) 'Mixing A Different Box of Chocolates - A Few Notes on Forrest Gump' http://filmsound.org/randythom/forrest.htm (accessed 30 August 2016)

Turim, Maureen (1989) Flashbacks in Film: Memory and History. New York and London: Routledge Williams, Linda (1991) 'Film Bodies: Gender, Genre, and Excess', Film Quarterly, 44 (4): 2-13

Winters, Ben (2008) 'Corporeality, Musical Heartbeats, and Cinematic Emotion', Music, Sound, and the Moving Image, 2:1: 3-26

\section{$\underline{\text { Media Cited }}$}

A Man Escaped, (Un condamné à mort s'est échappé) Robert Bresson, France, 1956

American Sniper, Clint Eastwood, US, 2014

Apocalypse Now, Francis Ford Coppola, US, 1979

Bashu, The Little Stranger (Bashu, gharibeye koochak), Bahram Beizai, Iran, 1990

The Beautiful Country, Hans Petter Moland, Norway/US, 2004

Boy from a War Movie (Djecak iz ratnog filma) Semsudin Gegic, Bosnia and Herzegovina, 2004

Casualties of War, Brian de Palma, US, 1989

Come and See (Idi I smotri), Hungary, Elem Klimov, 1985

Diamonds of the Night (Démanty noci), Jan Němec, Czechoslovakia, 1964

Forrest Gump, Robert Zemeckis, US, 1994

Grbavica: The Land of My Dreams, Jasmila Zbanic, Bosnia and Herzegovina, 2006

The Hurt Locker, Kathryn Bigelow, US, 2008

Platoon, Oliver Stone, US, 1986

Redacted, Brian de Palma, US, 2008

Saving Private Ryan, Steven Spielberg, US, 1998 
Breathing Bodies

The Thin Red Line, Terrence Malick, US 1998

Turtles Can Fly (Lakposhtha parvaz mikonand), Bahman Ghobadi, Iran, 2004

War Babies, Raymonde Provencher, Canada, 2004 


\section{Breathing Bodies}

1 The Vietnam War battle scene in Forrest Gump (Robert Zemeckis, 1994) might also be included in this list. See Randy Thom, 'Mixing A Different Box of Chocolates - A Few Notes on Forrest Gump' http://filmsound.org/randythom/forrest.htm (accessed 30 August 2016).

${ }^{2}$ In 'Her Body, Himself: Gender in the Slasher Film', Clover describes how the sounds of the killer's breath and heartbeat are aligned with the 'I-camera' to 'represent the killer's point of view' (1987: 208). She argues that although this may seem to force the spectator to identify with that character, processes of identification are much more 'elastic' than that would suggest. Clover's argument primarily focusses on image relations but in this essay, I wish to expand on her ideas around identification by shifting the focus to the role of sound and listening in these processes. See also Winters (2008)

${ }^{3}$ Here I take up, and expand on, some of the arguments put forward by Clover and Williams (1991) about the processes of identification involved in 'body genres' such as the slasher film and pornography which also use breath and embodiment as a way of 'drawing in' the spectator. An important distinction between these genres and the films I discuss however relates to the notion of spectatorial pleasure: while the films Clover and Williams discuss were unequivocally made to induce pleasure, the war film's relationship to historical and national events means that it potentially has a more complex mode of address. See also Lovatt (2015).

${ }^{4}$ See Kara (2009) for an interesting analysis of sound in relation to occupation.

${ }^{5}$ Ghobadi positions himself a Kurdish (or Kurdish-Iranian) filmmaker rather than Iranian but his films tend to be grouped with Iranian films. See Naficy (2012).

${ }^{6}$ While it is beyond the scope of this essay to discuss these in detail, some examples of films about war-rape and children include Grbavica: The Land of My Dreams (Jasmila Zbanic, 2006), The Beautiful Country (Hans Petter Moland, 2004) and the documentaries Boy from a War Movie (Djecak iz ratnog filma, Semsudin Gegic, 2004) and War Babies (Raymonde Provencher, 2004). See Carpenter (2010, 57) and Koebel (2009).

${ }^{7}$ See also Shahrzad Mojab. (2004); Moha Ennaji and Fatima Sadiqi (eds.). (2011) and Elizabeth D. Heineman (ed.). (2011). 